\title{
An Exploratory Study on Demand Sensing Approach to Develop Short-Term Forecasts Amid Covid-19 Pandemic in Cpg Industry
}

\author{
Anand Goyal' ${ }^{1}$, Dr. Kiran Karande ${ }^{2}$ \\ ${ }^{1}$ Student, Symbiosis Institute of Operations Management, Nashik, India \\ ${ }^{2}$ Assistant Professor, Symbiosis Institute of Operations Management, Nashik, India \\ ${ }^{1}$ anand.goyal@siom.in
}

\begin{abstract}
The research aims to identify the factors which can help in building Demand sensing capability in the CPG industry. Demand sensing refers to understanding of real-time market conditions to develop accurate forecast. This study uses empirical investigation of factors by conducting survey on random samples with people involved in demand planning role in CPG industry. There are 5 major factors which can help to understand demand at granular level (Digitization, Environment, Information Available, Supply chain Collaboration and Consumer Behaviour). Factors are identified by performing exploratory factor analysis on responses collected through questionnaire. Factor classification serves as a theoretical framework to develop demand sensing approach for better demand analysis during uncertain time like COVID-19 pandemic and how companies can leverage market insights into evolving their current demand forecasting capabilities from traditional time-series forecasting methods. The conceptual discussion in this research agenda can be used to incorporate these factors in the demand forecasting model can help better understanding of demand and better short-term forecasts in periods of uncertainty
\end{abstract}

Keywords

Demand Sensing, COVID-19, Demand Forecasting, Retail, Factor Analysis

Article Received: 10 August 2020, Revised: 25 October 2020, Accepted: 18 November 2020

\section{Introduction}

Demand sensing is an approach which involves translation of the downstream data in the supply chain with minimal latency to understand what is being sold, who is buying the product, and how the product is impacting the demand (Fary, 2010). Demand sensing, aids in demand forecasting by addition of other informational variables thus increasing accuracy of projection (Punekarnews, 2020). It uses new mathematical techniques and real-time data to accurately predict short-term demand, based on real-time information about the organization's supply chain. (GEP, 2020)

The COVID-19 pandemic radically impacted the customer buying behavior along with operations of the supply chains all around the world, this has created an enormous disruption which has brought uncertainty for teams who are responsible for planning. FMCG companies are seeing surges in demand, demand plummets, or both surge and plummets in some cases. (Llamasoft, 2020)

A highly disruptive event like COVID-19 has led a supply chain to shambles due to which time series forecasting methods, a backbone of a demand planner toolbox, may not be able to provide actionable prediction of demand as these methods rely on the fact the past events help in providing insight of the future (Llamasoft, 2020). Fast-changing events during a pandemic requires the right combination of data, technology along with human decision and can help in providing better insights which can help enterprises to maintain and adapt to the new environment.

As supply chains have evolved into huge networks making an ecosystem containing more and more vendors and spread across different locations, it has becoming increasingly difficult to maintain such supply chain cycles. To remain competitive, the supply chain needs to act fast in such an environment to have an edge and turning towards to demand sensing. (GEP, 2020)

Demand Sensing takes demand projection as an input variable. It then adds other available information like holiday calendar, yesterday's sales, customer research data, secondary sales data and gives breakdown of projection into finer grains of time and space. Demand forecasting which relies on time series and therefore can see only historical information while demand sensing can add many more intelligent variables along with historical information. In the process, it also enhances the accuracy of the projection. It provides short terms demand forecast with an accuracy which goes beyond the core trend and seasonality that might have been assessed from the past data analysis. (Punekarnews, 2020)

Forecasting demand in this uncertainty using traditional systems, data and processes don't provide the rigor necessary to plan the best response. Benefits the company have experienced using demand sensing approach includes a $5-10 \%$ improvement in cycle time and on-time delivery of products to store, a $15-40 \%$ improvement in short-term forecast accuracy, a 50\% reduction in Days Inventory on Hand, and improved market responsiveness, higher service levels and less obsolescence through more effective allocation decisions

The research aims to evaluate which factors to consider when applying a demand sensing model for developing short-term forecasts in a time of pandemic like COVID-19. Understanding the organization construct to be developed which can built to develop a flexible supply chain to incorporate demand sensing. 


\section{Literature Review}

On-going through the literature available on demand sensing approach we understood that in an uncertain environment performance of supply chain depends on how well it can "sense and respond" thereby mitigating risk of being broken-down by understanding the variations in demand or supply cycle which may be caused by internal or external factors across the business network. Which necessitates the need of integrated cross-enterprise planning and execution. The blending of "Command, Control, Sense and Respond" will help to provide CPG enterprise the platform of "knowledge" to continually analyze and learn from exceptions, and then incorporate this intelligence into our overall business processes (Fary, 2010).

During the COVID-19 pandemic, the traditional approach to demand forecasting was unable to capture the market dynamics and were plagued with human bias, human error, waste and inefficiencies.

Recent studies conducted by SAS shows, during the pandemic, $44 \%$ of retailers and CPG lack demand visibility from customers/ consumers $75 \%$ of products saw demand fluctuations companies were slightly better at responding to decreases rather than increases in demand $58 \%$ of retailers and CPG companies required a high degree of manual intervention and an increase in buffer stock to respond to fluctuations. Furthermore, CPG companies have been focused mainly on symptom rather than root cause. They are offsetting the demand through buffer stock which looks like a constrained supply plan and have not included a consumer mindset only reporting upstream to supply chain management.

A typical businesses project demand for the next 10 to 15 weeks as the time series models are now totally non applicable. There is an urgent need for newer advanced approach \& algorithms, which can help demand planners in this new world. This brings us to the nascent art of demand sensing.

Demand sensing has developed over the last few years as a tool for assisting demand planners in making demand projections more useful to the businesses. It is a tool for fine-grained break-down of projected demand into small units of time and space.

Demand Sensing includes 3 key elements

- $\quad$ Ability to increase volume and profit

- $\quad$ Supply supportably Analysis

- $\quad$ Demand Steering

The literature shows how demand is affected by different factors which lead to change in consumer buying behavior. Enforcement of lock-down induced new shopping behaviors among consumers which has led to frequent stock-outs and thus consumers were looking for substitutions. To meet the new demand, Companies had adopted new modes of operations mainly focused on the production of the item most in-need that are desirable amid the pandemic situation. For implementation, the brands need to oversee new supply chain strategies, and make collaboration with retail partners to have real-time visibility and make their supply chain flexible to meet their evolving needs. (TotalRetail, 2020). The consumer-focused approach is crucial in the crisis where manufacturers and retailers are going beyond to meet the evolving needs of the customer. Companies expect behavior changes post crisis as well and are simultaneously acclimating more to current reality and to be prepared for post-COVID future. (TotalRetail, 2020). Research has showed food e-commerce channels are more likely to be associated with panic stockpile behavior due to the higher likelihood of supply shortages than offline channels and anticipating this pattern CPG companies can plan better. (Hao et al., 2020). It was seen that due to fear of COVID-19 people started stock-piling food items (Hall et al., 2020) of some categories while it was also seen to induce change in consumer preferences while buying products. CPG companies are utilising demand sensing by leveraging POS and downstream data along with syndicated data to better understand their customers' demand (Charles W. Chase, 2014). Using this information to make better business and operational decisions. This helps to improve their short-term statistical demand forecasts. They normally define a "short term" as one to six weeks into the future. (Charles W. Chase, 2014). The COVID-19 pandemic is going to be an anchor point to transform the supply chain to be more adaptive and flexible (Mollenkopf et al., 2020) which can aid in developing of demand sensing model.

\section{Objectives of the Study}

Processing of literature reveals the need of demand sensing amid times of crisis for demand planning. Accordingly, this research delves into evaluating factors responsible for understanding changes in consumer demand and achieving improved short-term demand forecasts. Which brings us to our research question:

- RQ1. What external factors could have helped in predicting demand of CPG products amid COVID-19 pandemic?

RQ2. What organizational construct is needed to develop evolved demand analysis capability?

\section{Methodology}

\subsection{Background and Sample}

Data for the study was collected through online survey over period of August - September 2020 from social media site LinkedIn ${ }^{\mathrm{TM}}$. The survey was sent to various industry executives actively involved in demand planning roles in CPG industries. This survey acted as primary research for the subject of the study with main objective of collecting a survey was to outline the factors that should be included in developing a demand sensing model. A questionnaire survey-based instrument was used to elicit data from 187 respondents that participated in the survey. The questionnaire was floated through google form. The data presented in this article was obtained from respondents in the demand planning role. The questionnaire was such structured about how the use of specific variable can help in improve demand forecasting.

The survey was in 2 sections, A section comprised of collecting details of the CPG company respondent worked, their designation and the categorization of their role in 3 groups (Entry, Mid or Senior). All questions were made compulsory. 
The survey asked respondents to answer 19 questions from a set questionnaire. Each question was to be answered on the Likert scale up to 5. (1- Not useful, 5- Very Useful). Data Description of respondents are as follows:

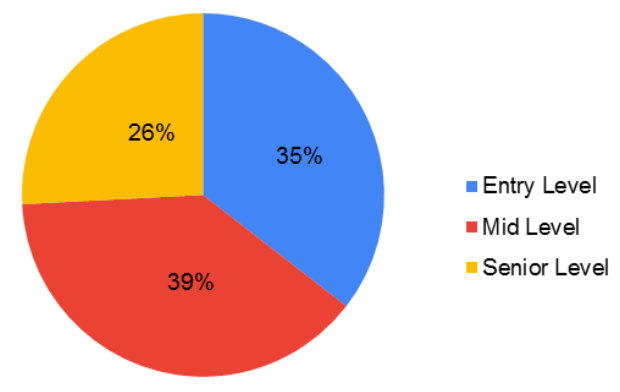

Figure 1: Respondents' roles in organization

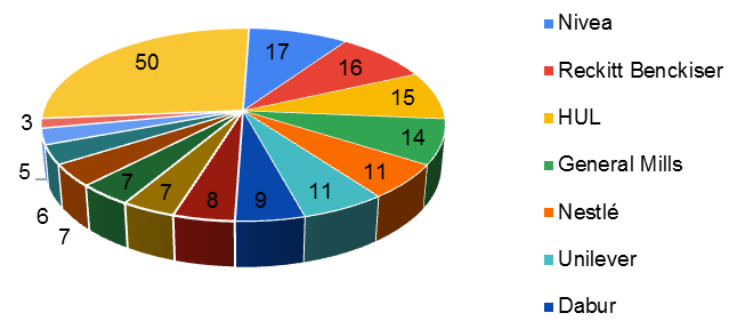

Figure 2: Respondents' Organizations

The majority of respondents belong from the CPG industry while some respondents of the survey were actively involved in consultancy in demand planning role for various CPG enterprises.

The section B comprised of questions related to the demand sensing approach

Table 1: Set of 19 items concerning demand sensing

\begin{tabular}{|c|c|c|}
\hline Variable & Item & Question in Survey \\
\hline V1 & $\begin{array}{l}\text { COVID-19 } \\
\text { cases }\end{array}$ & $\begin{array}{l}\text { Does demand pattern change } \\
\text { with the number of COVID- } \\
19 \text { spikes in a region? }\end{array}$ \\
\hline $\mathrm{V} 2$ & Lockdown & $\begin{array}{l}\text { What was the impact on } \\
\text { demand patterns with a } \\
\text { restriction on the movement } \\
\text { of goods during lock-down? }\end{array}$ \\
\hline V3 & Lifestyle & $\begin{array}{l}\text { According to you, what was } \\
\text { the major contributor to } \\
\text { stock-outs in March-April } \\
\text { months? }\end{array}$ \\
\hline V4 & $\begin{array}{l}\text { COVID-19 } \\
\text { Dashboard }\end{array}$ & $\begin{array}{l}\text { How helpful would COVID- } \\
19 \text { dashboards be for use for } \\
\text { the demand sensing } \\
\text { approach? }\end{array}$ \\
\hline V5 & $\begin{array}{l}\text { Product Shelf- } \\
\text { life }\end{array}$ & $\begin{array}{l}\text { Should product shelf life be } \\
\text { given preference in planning } \\
\text { demand during the COVID- } \\
19 \text { pandemic? }\end{array}$ \\
\hline V6 & E-commerce & $\begin{array}{l}\text { How likely consumers } \\
\text { preferred E-commerce mode } \\
\text { of orders during the COVID- } \\
19 \text { pandemic? }\end{array}$ \\
\hline V7 & POS Data & $\begin{array}{l}\text { According to you, Will } \\
\text { visibility of POS data of } \\
\text { retailers help in improving }\end{array}$ \\
\hline
\end{tabular}

\begin{tabular}{|c|c|c|}
\hline & & $\begin{array}{l}\text { short-term forecasts? (e.g. } \\
\text { weekly forecast) }\end{array}$ \\
\hline V8 & Syndicated data & $\begin{array}{l}\text { How helpful would } \\
\text { syndicated data by different } \\
\text { research organizations be in } \\
\text { demand identification at a } \\
\text { granular level? }\end{array}$ \\
\hline V9 & $\begin{array}{l}\text { Brand } \\
\text { Sentiment }\end{array}$ & $\begin{array}{l}\text { How likely due to stock-outs } \\
\text { did consumers bought } \\
\text { competitor's products? }\end{array}$ \\
\hline V10 & $\begin{array}{l}\text { Consumer } \\
\text { Sentiment }\end{array}$ & $\begin{array}{l}\text { According to you, how } \\
\text { effective is social media } \\
\text { analytics to help in } \\
\text { predicting the demand for } \\
\text { products? }\end{array}$ \\
\hline V11 & $\begin{array}{l}\text { Digital } \\
\text { Marketing }\end{array}$ & $\begin{array}{l}\text { How effective were digital } \\
\text { media marketing to increase } \\
\text { demand during COVID-19? }\end{array}$ \\
\hline V12 & $\begin{array}{l}\text { Government } \\
\text { Statements }\end{array}$ & $\begin{array}{l}\text { According to you, is there a } \\
\text { change in consumer buying } \\
\text { behaviour based on } \\
\text { government statements on } \\
\text { COVID-19? }\end{array}$ \\
\hline V13 & IT Enablement & $\begin{array}{l}\text { Do you think better IT } \\
\text { enablement in downstream } \\
\text { would have helped in better } \\
\text { demand forecasting? }\end{array}$ \\
\hline V14 & $\begin{array}{l}\text { Analytical } \\
\text { Capability }\end{array}$ & $\begin{array}{l}\text { How would you rate the use } \\
\text { of the advanced analytical } \\
\text { capability to aid in better } \\
\text { demand forecasting? }\end{array}$ \\
\hline V15 & IoT Application & $\begin{array}{l}\text { How likely is anticipation of } \\
\text { demand pattern possible with } \\
\text { the application of IoT in } \\
\text { downstream? }\end{array}$ \\
\hline V16 & $\begin{array}{l}\text { Business } \\
\text { Intelligence }\end{array}$ & $\begin{array}{l}\text { If CPG enterprises were to } \\
\text { extend analytical capabilities } \\
\text { like BI reporting tools to } \\
\text { retailers how helpful it } \\
\text { would have been to provide } \\
\text { better demand pattern } \\
\text { identification? }\end{array}$ \\
\hline V17 & Flexibility & $\begin{array}{l}\text { How would you rate } \\
\text { flexibility of distribution } \\
\text { network to be factor for } \\
\text { better demand fulfilment } \\
\text { during } \\
\text { pandemic? }\end{array}$ \\
\hline V18 & $\begin{array}{l}\text { Risk } \\
\text { Assessment }\end{array}$ & $\begin{array}{l}\text { How important is risk } \\
\text { assessment and planning in } \\
\text { handling demand surges? }\end{array}$ \\
\hline V19 & $\begin{array}{l}\text { Channel } \\
\text { Strategy }\end{array}$ & $\begin{array}{l}\text { How important is to re- } \\
\text { model channel strategy to } \\
\text { build stronger relationship } \\
\text { with consumers? }\end{array}$ \\
\hline
\end{tabular}

\subsection{Statistical Analysis}

Exploratory Factor Analysis was used to reduce observable variables to fewer latent variables which are sharing common variance to reduce dimensionality of the variables 
under measurement. The factors will be measured based on variables represented them, focusing only on key factors instead to considering that may be trivial.

Before starting the process of extracting factors, it is necessary to perform a test on the sample data. The two tests which are commonly used is "Kaiser-Meyer-Olkin (KMO) Measure of adequacy of the sample" [Kaiser HF, 1975] and "Bartlett's Test of Sphericity" [Bartlett MS,1950]. The value of $\mathrm{KMO}$ is between 0 and 1. A value greater than 0.50 indicates the sample data is sufficient and factor analysis can be done. The "Bartlett's Test of Sphericity" should be significant $(\mathrm{p}<0.05)$ such that it is eligible for factor analysis. The KMO test came out be 0.650 , which is above the recommended cut-off of 0.5 and "Bartlett's Test of Sphericity" came out to be 0.000 . The KMO criterion and Bartlett's test indicate that data is appropriate to perform EFA on the data set.

We used principal component factor analysis VARIMAX rotation to reduce to factors as it allowed clear interpretation of factors. The number of factors to be extracted should be having eigenvalues greater than 1 (Kaiser, 1960). The factor extraction was conformed using parallel calculation (Patil Vivek H, 2017).

\section{Results and Discussion}

\subsection{Factor Structure}

Exploratory Factor Analysis yielded 5 factors. The factors obtained after orthogonally rotating extracting component factors using varimax rotation method. These factors determine which parameters are to be included in the demand sensing model. Total explained variance together is $61 \%$ after rotating component factors. In variable item lifestyle and government statements observed variable loading on any of the factors was less than 0.4 and was omitted from the model. loading on these factors are listed in the table given below:

Table 2: Results of the exploratory factor analysis displayed

\begin{tabular}{|c|c|c|c|c|c|}
\hline Item & $\begin{array}{l}\text { F1 } \\
\text { Digitalizati } \\
\text { on }\end{array}$ & $\begin{array}{l}\text { F2 } \\
\text { Informati } \\
\text { on } \\
\text { Availabili } \\
\text { ty }\end{array}$ & $\begin{array}{l}\text { F3 } \\
\text { Environme } \\
\text { ntal }\end{array}$ & $\begin{array}{l}\text { F4 } \\
\text { Supply } \\
\text { Chain } \\
\text { Collaborati } \\
\text { on }\end{array}$ & $\begin{array}{l}\text { F5 } \\
\text { Consum } \\
\text { er } \\
\text { Behavio } \\
\text { ur }\end{array}$ \\
\hline $\begin{array}{l}\text { IT } \\
\text { enableme } \\
\text { nt }\end{array}$ & 0.500 & & & & \\
\hline $\begin{array}{l}\text { Analytica } \\
1 \\
\text { Capabilit } \\
\text { y }\end{array}$ & 0.547 & & & & \\
\hline IoT & 0.872 & & & & \\
\hline $\begin{array}{l}\text { Business } \\
\text { Intelligen } \\
\text { ce }\end{array}$ & 0.738 & & & & \\
\hline POS Data & 0.700 & & & & \\
\hline $\begin{array}{l}\text { Consumer } \\
\text { Sentiment }\end{array}$ & & 0.840 & & & \\
\hline $\begin{array}{l}\text { Syndicate } \\
\text { d Data }\end{array}$ & & 0.872 & & & \\
\hline $\begin{array}{l}\text { Digital } \\
\text { Marketin } \\
\mathrm{g}\end{array}$ & & 0.845 & & & \\
\hline $\begin{array}{l}\text { COVID- } \\
19 \text { spikes }\end{array}$ & & & 0.881 & & \\
\hline $\begin{array}{l}\text { Lock- } \\
\text { down }\end{array}$ & & & 0.905 & & \\
\hline $\begin{array}{l}\text { COVID- } \\
19\end{array}$ & & & 0.846 & & \\
\hline
\end{tabular}

\begin{tabular}{llll}
\hline $\begin{array}{l}\text { Dashboar } \\
\text { ds }\end{array}$ & $\mathbf{0 . 8 2 8}$ & \\
\hline $\begin{array}{l}\text { Flexibilit } \\
\text { y }\end{array}$ & $\mathbf{0 . 9 0 0}$ & \\
\hline $\begin{array}{l}\text { Risk } \\
\text { Assessme } \\
\text { nt }\end{array}$ & & \\
\hline $\begin{array}{l}\text { Channel } \\
\text { Strategy }\end{array}$ & $\mathbf{0 . 8 4 4}$ & \\
\hline $\begin{array}{l}\text { Product } \\
\text { Shelf-life }\end{array}$ & & $\mathbf{0 . 8 6 8}$ \\
\hline $\begin{array}{l}\text { E- } \\
\text { commerc }\end{array}$ & & & $\mathbf{0 . 8 3 9}$ \\
e & & & \\
\hline $\begin{array}{l}\text { Brand } \\
\text { Sentiment }\end{array}$ & & $\mathbf{0 . 7 2 1}$ \\
\hline Lifestyle & & & \\
\hline $\begin{array}{l}\text { Governm } \\
\text { ent }\end{array}$ & & & \\
Statement \\
s
\end{tabular}

\subsection{Reliability of Constructs}

The identified constructs are considered to be reliable if the Cronbac's Alpha value is greater than 0.7 for all the constructs. In our study the identified constructs passed the Cronbac's Aplha test, i.e. all $>0.7$.

Table 3: Reliability of each construct

\begin{tabular}{|c|c|c|c|c|}
\hline F1 & F2 & F3 & F4 & F5 \\
\hline $\begin{array}{l}\text { Digitaliza } \\
\text { tion }\end{array}$ & $\begin{array}{l}\text { Informa } \\
\text { tion } \\
\text { Availabi } \\
\text { lity }\end{array}$ & $\begin{array}{l}\text { Environm } \\
\text { ental }\end{array}$ & $\begin{array}{l}\text { Supply } \\
\text { Chain } \\
\text { Collabora } \\
\text { tion }\end{array}$ & $\begin{array}{l}\text { Consu } \\
\text { mer } \\
\text { Behavi } \\
\text { our }\end{array}$ \\
\hline 0.725 & 0.840 & 0.858 & 0.835 & 0.766 \\
\hline
\end{tabular}

\subsection{Interpretation of Results}

By performing EFA we were able to interpret five factors. Each variable under the construct interpretation is as follows:

F1 Digitalization: The first factor represents the digital capability needed for making a better demand sensing model for an organization. The enablement of IT will help in better information collaboration between stakeholders. Analytical Capability helps in performing complex mathematical structural problem and predicting of demand based on different algorithms. Application of IoT will help in getting real-time access to information of inventory, like IoT enabled trucks help in tracking pipeline inventory which helps in better planning also the IoT application can help in giving better accessibility of inventory available with retailers. Sharing of POS data from retailers will help CPG enterprises to understand the demand pattern, better helping them plan product in high demand. Amid this pandemic, different product had different demand and availability of real-time information planner can plan better transportation routes for demand fulfillment and can predict demand for upcoming days. Extending BI capabilities to retailers helps mom-pop stores or small shopping marts to better track the demand pattern which can be shared with enterprises or distribution center aiding in demand sensing capabilities F2 Information Availability: Informational availability refers to external information used to improve demand forecasting, Consumer sentiment calculated using social media analytics by analyzing data generated through various 
social media sites like Facebook ${ }^{\mathrm{TM}}$, Twitter ${ }^{\mathrm{TM}}$ etc. helps to analyze the purview of consumers. Amid pandemic consumers were confined to homes and had varied eating preferences which led to an increase in demand of certain products understanding the behavior changes through social media posts can help enterprises understand consumer preference, helping to meet demand of consumers. Syndicated data are made available through different research institution like Nielson $^{\mathrm{TM}}$ which can give an overview of demand from different regions which can help CPG enterprises understand the demand schematics from other region only disadvantages there might be delay in reports by the organizations by which demand may have been subsided. The COVID-19 pandemic has confined consumers to home and the campaign being launched online through digital marketing initiatives can help in capturing market share and can also be used to increase brand presence and due to stock-outs of other brands' customer will be willing to try out new alternatives.

F3 Environmental: The construct means demand affected due to increasing infections due to COVID-19 pandemic. Spike in COVID-19 cases can affect demand in a particular region as more cases rise and due imposition of lockdown led to disruption in meeting the demand. COVID-19 dashboards can help in understanding spikes in a region along with a restriction in movement due to containment zone which can affect demand of the CPG products.

F4 Supply Chain Collaboration: The construct defines the role of supply chain collaboration in improving demand sensing capabilities in a CPG enterprise. Flexibility helps in making changes according to demand quickly. Amid this pandemic, many products' requirement went down. Enterprises can utilize resources and lines to start manufacturing of the product in demand to meet rising demand. Distribution should be made flexible that it can handle minute changes in demand plans. Risk Assessment is necessary to mitigate any supply chain challenges through collaboration between shareholders helps in better demand fulfillment. Channel Strategy defines the multi-channel approach of demand fulfillment like D2C (Direct to Consumers) or through third party online stores. This helps in better demand tracking and with a flexible network able to sense demand for a particular product.

F5 Consumer Behaviour: Changing consumer behavior is also a factor which can help in demand sensing. During COVID-19 pandemic consumer preferred products with better shelf-life it can be attributed to some part fear of the pandemic. As the movement was restricted during COVID19, the consumers preferred placing order through ecommerce website. Demand tracking through e-commerce is relatively efficient as it helps in better analytical capabilities. Due to stock-outs, the consumer has access to similar products from another brand which makes the customer churn possible, which can lead to a decrease in brand sentiment. Inclusion of brand sentiment calculation can help in improving demand estimates.

\subsection{Discussion: Building evolved demand analysis capability}

Paper discussed about the factors which can help in developing demand sensing capabilities in a CPG industry during times of uncertainties during COVID-19 pandemic. While it is still impossible to predict all the COVID-19 impact but adapting to changing circumstances can help the supply chain be efficient even during such times.

COVID-19 pandemic can lay foundation for better demand analysis capabilities, CPG enterprises after resumption of operations should do strategic planning for integrated forecasting of demand (Llamasoft, 2020).

The demand planning capability can be divided into 3 groups:
1. Near Term Plan
2. Mid Term Plan
3. Long Term Plan

Near Term: Building a demand sense model using the factors identified above; knowing the consumer better by analyzing the POS data, understanding the COVID -19 impact and its magnitude in different regions. Understanding changing consumer behavior with close attention by doing social media analysis. Segmenting and prioritizing the product by understanding the demand pattern and using machine learning algorithms to develop automated forecasting for demand of volatile products.

Mid Term: Measuring shifts in demand by understanding the change points attributed to macro-economic indicators, trade inventory and digital promotions etc. to develop an advanced demand forecasting technique leveraging deep learning algorithms. Evaluate the model by running simulations using what-if analysis and developing contingency plans and understanding potential impacts and unavoidable changes, this will help in identifying weak links in the value chain and build better supply chain resilience. Frequent revision of forecasts enabling correction of the imbalances

Long Term: Using a univariate model like ARIMA or exponential smoothing will not be able to capture seasonality or trend due to the presence of noise due to the COVID-19 pandemic demand surges. Developing better market sensing capabilities and leveraging dynamic forecasting which includes use of external variables inaddition to traditional time-series forecasts.

\section{Conclusion}

The paper presented used exploratory factor analysis (EFA) to describe 5 factors important to develop a demand sensing approach in a CPG Enterprise. After undergoing review of literature from different research articles and white papers, it was identified 19 variables whose impact can help in understanding the demand pattern to develop forecasts in short-term. This classification of 19 variables into 5 factors were done using principal component analysis technique. This classification serves as a theoretical framework to develop demand sensing approach for better demand analysis during uncertain time like COVID-19 pandemic.

In addition, we also provide an evolving demand analysis capability that all CPG enterprise should develop to deal with any such uncertain in future like COVID-19 which is divided into 3 terms in short-term for immediate action and resuming operations, mid-term for adapting by analyzing market insights to develop better demand forecasting model and long-term for evolving into resilient supply chain. 


\section{References}

[1] Charles W. Chase, J. (2014). Using Demand Sensing and Shaping to Improve Demand Forecasting. Journal of Business Forecasting, 24-31.

[2] Fary, G. (2010). Demand Sensing in Volatile Times. Journal of Business Forecasting, 31-33.

[3] Kaiser, H. F. (1960). The application of electronic computers to factor analysis. Educational and psychological measurement, 141-151.

[4] Hao, N., Wang, H. H., \& Zhou, Q. (2020). The impact of online grocery shopping on stockpile behavior in Covid-19. China Agricultural Economic Review, 12(3), 459-470. https://doi.org/10.1108/CAER04-2020-0064.

[5] Hall, M. C., Prayag, G., Fieger, P., \& Dyason, D. (2020). Beyond panic buying: consumption displacement and COVID19. Journal of Service Management.

[6] Mollenkopf, D. A., Ozanne, L. K., \& Stolze, H. J. (2020). A transformative supply chain response to COVID-19. Journal of Service Management.

[7] Patil Vivek H, S. N. (2017). Parallel Analysis Engine to Aid in Determining Number of Factors to Retain using $\mathrm{R}$ [Computer software]. Retrieved from Parallel Analysis: https://analytics.gonzaga.edu/parallelengin e/

[8] TotalRetail. (2020, April 28). COVID-19: Impact on CPG and Retail. Retrieved from My Total Reatil: https://www.mytotalretail.com/article/covi d-19-impact-on-cpg-and-retail/

[9] Company, M. \&. (2020, 8 11). Rapidly forecasting demand and adapting commercial plans in a pandemic. Retrieved from McKinsey \& Company: https://www.mckinsey.com/industries/cons umer-packaged-goods/ourinsights/rapidly-forecasting-demand-andadapting-commercial-plans-in-apandemic.html
[10] GEP. (2020, June). Demand Sensing A Critical Supply Chain Capability for the Now Economy. Retrieved from GEP Worldwide.

[11] Llamasoft. (2020). COVID-19 Demand Impact Analyzer. Retrieved from Llamasoft: https://llamasoft.com/covid-19demand-impact-analyzer/

[12] Punekarnews. (2020, June). Demand sensing algorithms to fine tune business demand projection estimates in COVID times. Retrieved from Punekar news: https://www.punekarnews.in/demandsensing-algorithms-to-fine-tune-businessdemand-projection-estimates-in-covidtimes/ 